\title{
Morphology evidences the lophophorates monophyly: brief review of studies on the lophophore innervation
}

\section{Elena N. Temereva}

Dept. of Invertebrate Zoology, Biological Faculty, Moscow State University, Moscow, Russia. Email: temereva@mail.ru

ABSTRACT: The status of the Lophophorates is one of the central problems of current zoology. There is a contradiction between the molecular results, which mainly indicate the polyphyly of the lophophorates, and morphological results, which indicate the monophyly of the lophophorates. An understanding of lophophore innervation can help answer question about the status of the lophophorates. Data on the lophophore innervation, which were obtained by methods of immunocytochemistry, transmission electron microscopy, and laser confocal scanning microscopy in species from all three groups of the lophophorates, are summarized in this report. According to morphological results, the lophophore has several main nerves that seem to be homologous among different lophophorates. The main brachial nerve of brachiopods is homologous to the dorsal ganglion of phoronids and to the cerebral ganglion of ectoprocts. The accessory brachial nerve of brachiopods is homologous to the minor nerve ring of juvenile phoronids and to the circum oral nerve of ectoprocts. The lower brachial nerve of brachiopods is homologous to the tentacular nerve ring of phoronids and to the outer nerve of ctenostome ectoprocts. Morphological data on the lophophore innervation indicate that the Lophophorata is monophyletic group including three phyla: Phoronida, Brachiopoda, and Bryozoa. Contradiction between morphological and molecular results might be explained by of bryozoans, whose evolution was associated with great morphological and, apparently, molecular changes. To reject the lophophorates monophyly we should suggest the independent origin of the lophophore - a specific tentacular structure having specific innervation - in both Bryozoa and Brachiozoa (= Phoronida + Brachiopoda).

How to cite this article: Temereva E.N. 2017. Morphology evidences the lophophorates monophyly: brief review of studies on the lophophore innervation // Invert. Zool. Vol.14. No.1. P.85-91. doi: 10.15298/invertzool.14.1.12

KEY WORDS: morphology, nervous system, lophophore, Phoronida, Brachiopoda, Bryozoa, phylogeny.

\section{Морфология свидетельствует о монофилии Lophophorata: краткий обзор данных об иннервации лофофора}

\section{Елена Н. Темерева}

Кафедра зоологии беспозвоночных, биологический факультет, Московский государственный университет имени М.В. Ломоносова, Москва, Россия. E-mail: temereva@mail.ru

РЕЗЮМЕ: Вопрос статуса группы Lophophorata является одной из центральных проблем современной зоологии. Современные данные молекулярной филогенетики 
свидетельствуют о парафилии группы и противоречат традиционному мнению о единстве лофофорат, как таксона надтипового ранга, включающего три типа беспозвоночных животных: форонид, брахиопод и мшанок. Изучение организации лофофора - особого щупальцевого органа, традиционно рассматривающегося как наиболее очевидная морфологическая синапоморфия лофофорат, позволит пролить свет на вопрос статуса группы. В работе обобщены данные, полученные при изучении нервной системы лофофора у представителей всех трех групп лофофорных животных методами иммуноцитохимии, лазерной конфокальной микроскопии и трансмиссионной электронной микроскопии. Анализ полученных данных свидетельствует о существовании гомологичных нервов лофофора у изученных видов из разных групп лофофорат. Так, главный брахиальный нерв у брахиопод соответствует дорсальному нервному сплетению форонид и церебральному ганглию мшанок. Добавочный брахиальный нерв брахиопод соответствует малому нервному кольцу форонид и циркуморальному нерву мшанок. Нижний брахиальный нерв брахиопод соответствует главному щупальцевому нервному кольцу мшанок и внешнему нерву у ктеностомных мшанок. Наличие гомологичных нервов позволяет утверждать гомологию лофофора и подтверждает монофилию Lophophorata как группы, включающей форонид, брахиопод и мшанок. Противоречие между молекулярными и морфологическими данными, возможно, определяется своеобразием мшанок, чья эволюция была связана с существенными изменениями на морфологическом и, очевидно, на генетическом уровнях. Для того, чтобы отвергнуть идею монофилии лофофорат необходимо предположить, что такая особая структура как лофофор, имеющая специфическую морфологию и иннервации, возникла в эволюции дважды и не зависимо у Brachiozoa (= форониды + брахиоподы) и у Bryozoa.

Как цитировать эту статью: Temereva E.N. 2017. Morphology evidences the lophophorates monophyly: brief review of studies on the lophophore innervation // Invert. Zool. Vol.14. No.1. P.85-91. doi: 10.15298/invertzool.14.1.12

КЛЮЧЕВЫЕ СЛОВА: морфология, нервная система, лофофор, форониды, брахиоподы, мшанки, филогения.

The presence of the lophophore - which is a part of the mesosome and which has tentacles and functions in respiration and food capture - is the most prominent feature in the lophophorates. In all lophophorates, the tentacles of the lophophore surround the mouth but never the anus. It follows that entoprocts, whose tentacles surround both the mouth and the anus, cannot be regarded as lophophorates. Consideration of the lophophore allowed researchers to combine phoronids, brachiopods, and ectoprocts into a united clade, the Lophophorata (Hyman, 1954; Emig, 1976). The unity of the Lophophorates has not been supported, however, by some recent molecular phylogenetic data (Hausdorf et al., 2010; Kocot et al., 2017). According to these data, phoronids and brachiopods are close relatives and form the clade Brachiozoa, whereas ectoprocts form a separate clade whose position in the phylogenetic tree is unclear. At the same time, fewer recent molecular phylogenetic studies support the monophyly of the lophophorates but not the unity of the Brachiozoa (Jang, Hwang, 2009; Nesnidal et al., 2013). Our previous morphological data, on the other hand, revealed the similarity in organization of the lophophore nervous system among different lophophorates (Temereva, Tsitrin, 2015; Temereva, Kosevich, 2016). These morphological results argue for the homology of the lophophores in lophophorates and support the unity of the clade Lophophorata. At the same time, correct comparative analysis requires the involving of 
more and more specimens from all three groups of the lophophorates. This report contains review of morphological results on innervation of the lophophore in the lophophorates.

\section{Organization of the lophophore nervous system in phoronids}

The lophophore nervous system in adult phoronids has seldom been studied with modern methods. The detailed investigation was done by histological methods (Silen, 1954). Ultrastructure of main nerve elements and nervous tracts in tentacles was studied in several phoronid species (Pardos et al., 1991; Fernández et al., 1996; Temereva, Malakhov, 2009). According to all these results, nervous system of the lophophore in adult phoronids includes dorsal nerve plexus (=dorsal ganglion?), tentacular nerve ring, and nerve tracts in tentacles. The dorsal nerve plexus is located between mouth and anus, on the dorsal side of animal. It mostly consists of perikarya of large diameter, which are apparently motoneurons (Temereva, Malakhov, 2009). The tentacular nerve ring extends at the tentacles base, along the outer side of the lophophore and repeats its shape. The tentacular nerve ring mostly consists of repikarya of small diameter, which are apparently sensory. Innervation of tentacles is the most difficult question. Accordingly to most results, in each tentacle there are two nerve tracts, which extend along frontal and abfrontal sides (Pardos et al., 1991; Temereva, Malakhov, 2009). Both tentacular nerve tracts originate from the tentacular nerve ring. Frontal and abfrontal tentcular nerve tracts develop similarly in terms of the number of bundles and number of axons per bundle (Pardos et al., 1991). Specific laterofrontal sensory cells are associated with the frontal nerve tract (Fernández et al., 1996).

According to new results, which were obtained from juvenile phoronids (Temereva, Tsitrin, 2014), innervation of the lophophore a bit differs from the tradition scheme described above. In addition to dorsal ganglion and the tentacular nerve ring, the lophophore of juve- nile Phoronopsis harmeri is innervated by the minor (=inner) nerve ring, which extends along the inner side of the lophophore (Fig. 1A). In comparison with the tentacular nerve ring, the inner nerve ring develops weak, consists of several neurites, and does not associated with prominent perikarya. In juvenile $P$. harmeri, each tentacle is innervated by six nerve tracts: one frontal, two laterofrontal, two lateroabfrontal, and one abfrontal. The lateroabfrontal nerve tracts are usually associated with large gland cells, whereas the laterofrontal bundles are located near sensory laterofrontal cells. The frontal nerve tracts originates from the inner nerve ring; the laterofrontal nerve tracts seems to be unconnected with any nerve tracts of the lophophore. Two lateroabfrontal nerve tracts start from the intertentacular nerves, which originate from the tentacular nerve ring and extend between tentacles at their base. Abfrontal nerve tract starts from the tentacular nerve ring (Temereva, Tsitrin, 2014).

In tentacles of all studied phoronid species the peritoneal neurites (axons?) were found (Pardos et al., 1991; Temereva, 2015). These neurites run between the peritoneal cells and the basement membrane. Peritoneal neurites are characterized by large diameter, electron lucent cytoplasm, and presence of thick microtubules.

\section{Organization of the lophophore nervous system in brachiopods}

Innervation of the lophophore in brachiopods is poorly studied by modern methods. The organization of the lophophore nervous system in brachiopods has usually been studied via light microscopy (van Bemmelen, 1883; Blochmann, 1892, 1900). There are, however, some transmission electron microscopy data on the innervation of brachiopod tentacles (Storch, Welsch, 1976; Reed, Cloney, 1977; James, 1997). The most recent results, which were obtained by confocal laser scanning microscopy and immunocytochemistry, concerned the innervation of the lophophore and tentacles in the inarticulate brachiopod Lingula anatina 


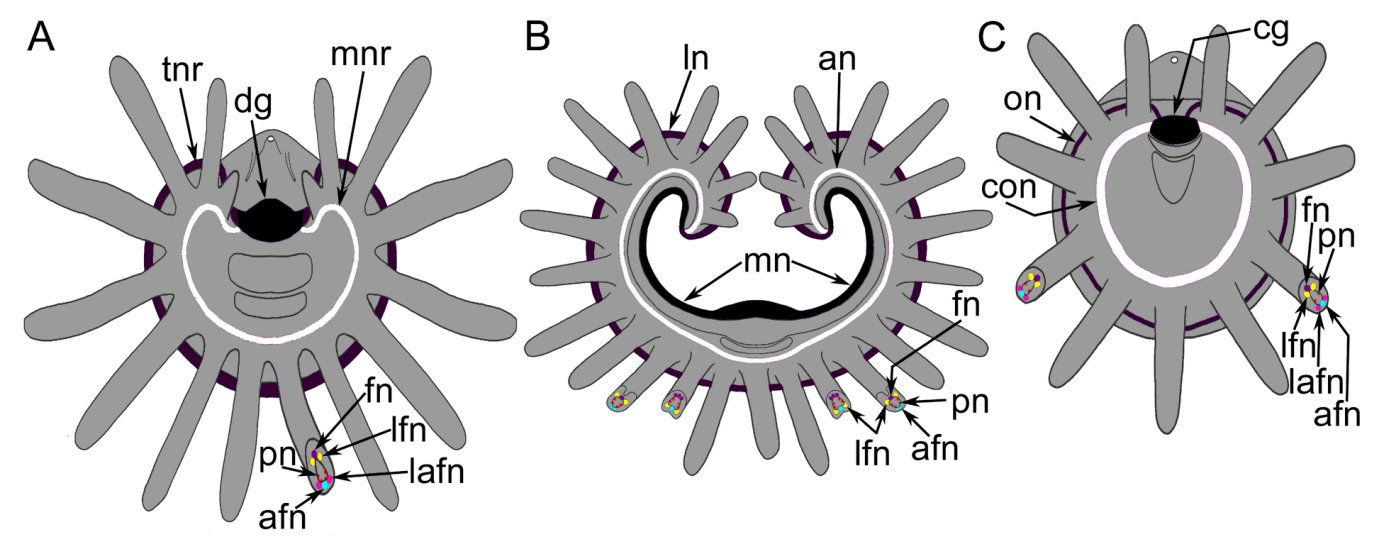

Fig. 1. Schemes of the lophophore and tentacles innervation in the lophophorates. A - juvenile phoronids (based on Temereva, Tsitrin, 2014); B — inarticulate brachiopods (based on Temereva, Tsitrin, 2015); C - ctenostome bryozoans (based on Temereva, Kosevich, 2016). Homologous elements are shown by similar color. Abbreviations: afn — abfrontal tentacular nerve; an — accessory brachial nerve; cg — cerebral ganglion; con - circumoral nerve ring; $\mathrm{dg}$ - dorsal ganglion; $\mathrm{fn}$ - frontal tentacular nerve; lafn lateroabfrontal tentacular nerve; lfn — laterofrontal tentacular nerve; ln — lower brachial nerve; $\mathrm{mn}$ - main brachial nerve; $\mathrm{mnr}$ - minor nerve ring; $\mathrm{pn}$ - peritoneal neurite; $\mathrm{tnr}$ - tentacular main nerve ring.

Рис. 1. Схемы иннервации лофофора и щупалец у лофофорат. А - лофофор ювенильной форониды (по: Temereva, Tsitrin, 2014); В — лофофор беззамковой брахиоподы (по: Temereva, Tsitrin, 2015); C - лофофор ктеностоматной мшанки (по: Temereva, Kosevich, 2016). Гомологические элементы показаны одинаковым цветом. Обозначения: afn - абфронатльный нерв щупальцае; an — добавочный брахиальный нерв; cg — церебральный ганглий; con — циркуморальное нервное кольцо; $\mathrm{dg}$ дорсальный ганглий; fn — фронтальный щупальцевый нерв; lafn — латероабфронтальный щупальцевый нерв; lfn — латерофронтальный щупальцевый нерв; ln — нижний брахиальный нерв; $\mathrm{mn}$ главный брахиальный нерв; $\mathrm{mnr}$ - малое (внутреннее) нервное кольцо; pn — перитонеальные нервы щупалец; $\mathrm{tnr}$ - щупальцевое нервное кольцо.

(Lamark, 1801), which has a spirolophe type of lophophore (Temereva, Tsitrin, 2015).

According to all these data, brachiopod lophophore is innervated by three brachial nerves: main, accessory, and lower (Fig. 1B). The main brachial nerve passes along the external side of the base of the brachial fold - an epithelial fold, which covers the mouth and bases of tentacles of inner row. The main brachial nerve is connected to the accessory brachial nerve, which passes along the food groove. This connection is provided by thick cross nerves, which extend into the connective tissue of the brachial fold. The lower brachial nerve extends along the bases of the outer tentacles.

In most of brachiopods, there are two rows of tentacles: inner and outer. In each tentacle, there are six nerve tracts: one frontal, two laterofrontal, two lateroabfrontal, and one abfrontal.
Frontal and two laterofrontal tentacular nerves emanate from the accessory brachial nerve, whereas abfrontal and lateroabfrontal tentacular nerves originate from the lower brachial nerve. In Lingula anatina, there are intertentacular nerves, which start from the accessory brachial nerve and which give rise to the frontal and laterofrontal tentacular nerves (Temereva, Tsitrin, 2015).

In L. anatina and Hemithiris psittacea peritoneal neurites were found in tentacles of both inner and outer rows (Temereva, Tsitrin, 2015; Temereva, Kuzmina, in press). In H. psittacea peritoneal neurites exhibit strong immunorectivity against acetylated alpha tubulin and serotonin (Temereva, Kuzmina, in press). Peritoneal neurites are characterized by large diameter, electron lucent cytoplasm, and presence of thick microtubules. 


\section{Organization of the lophophore nervous system in bryozoans}

Many reports have described the innervation of the lophophore and tentacles in many different bryozoans from all of taxa, except Stenolaemata (Lutaud, 1973; Gordon, 1974; Schwaha et al., 2011; Schwaha, Wanninger, 2012; Weber et al., 2014; and many others). These data indicate great variation in the organization of the bryozoan nervous system. The variations concern organization of the cerebral ganglion, innervation of tentacles, and connections between tentacular neurite bundles and the main nerve centers. These numerous results were reviewed and analyzed in several recent papers that presented ideas about general patterns of the tentacle innervation and the localization of the lophophore main nerve tracts in all bryozoans (Shunkina et al., 2015; Schwaha, Wanninger, 2015). All these researches evidence the presence in bryozoans cerebral ganglion and inner nerve ring of the lophophore (=circumoral nerve ring). According to new results, which were obtained for ctenostome bryozoans, there is outer nerve ring passing along the outer side of the lophophore (Temereva, Kosevich, 2016) (Fig. 1C).

In general, bryozoans possess four to six longitudinal neurite bundles: one medio-frontal nerve, one abfrontal nerve, and one pair of the laterofrontal nerves. Most phylactolaemates have six basiepidermal tentacular nerves: mediofrontal, medioabfrontal, one pair of lateroabfrontal, and one pair of laterofrontal (Shunkina et al., 2015). Gymnolaemates in general have four tentacular nerves: one abfrontal, one mediofrontal, and one pair of laterofrontal (Weber et al., 2014; Schwaha, Wood, 2011). Based on their origin, two main types of tentacular nerves occur in bryozoans. The first type is common in phylactolaemates and is characterized by the branching of all tentacular nerves from intertentacular (radial) nerves (Shunkina et al., 2015). The second type occurs in gymnolaemata in which some nerves originate from intertentacular nerves and others originate directly from the circum-oral nerve ring (Lutaud, 1973; Schwaha, Wood, 2011; Weber et al., 2014). There are some variations in the second type. For example, in most of the gymnolaemates, the mediofrontal nerves arise from the circum-oral nerve ring while the abfrontal and the latero-frontal nerves branch from the intertentacular nerves. In E. pilosa, in contrast, the abfrontal nerve also originates from the circum-oral nerve ring (Lutaud, 1973).

In addition to six or four basiepidermal nerves, many ectoprocts have two basiperitoneal tentacular nerves (Mukai et al., 1997; Weber et al., 2014; Temereva, Kosevich, 2016). According to some data (Weber et al., 2014), these neurites do not show immunoreactivity against acetylated alpha tubulin and thereby cannot be regarded as nerve elements.

\section{Conclusion}

The lophophore has several main nerves that seem to be homologous among different lophophorates. For example, the main brachial nerve extending along the dorsal side of the brachial fold of brachiopods is homologous to the dorsal ganglion of phoronids and to the cerebral ganglion of ectoprocts. The accessory brachial nerve passing along the frontal side of tentacles of brachiopods is homologous to the minor nerve ring of juvenile phoronids and to the circum oral nerve of ectoprocts. The lower brachial nerve extending along the abfrontal side of tentacles of brachiopods is homologous to the tentacular nerve ring of phoronids and to the outer nerve of ctenostome ectoprocts. The presence of such an unusual element as basiperitoneal neurites makes the innervation of tentacles in all lophophorates quite similar and together with other common features of the lophophore neuroarchitecture suggest the homology of the lophophore (Fig. 1).

Although the general morphology of the lophophore and its nervous system looks very similar in the lophophorates, the location of tentacles and the zones where new tentacles form are different in brachiopods than in phoronids and ectoprocts. The macroscopic resem- 
blance of the lophophore in phoronids and ectoprocts is consistent with the idea that these groups are closely related and rejects the hypothesis of Brachiozoa, which includes phoronids and brachiopods (Temereva, Malakhov, 2011; Nesnidal et al., 2013).

Overall, there is a contradiction between the molecular results, which mainly indicate the polyphyly of the lophophorates, and morphological results, which indicate the monophyly of the lophophorates. This contradiction may be explained by the specificity of bryozoans. Although the morphologies of brachiopods, phoronids, and bryozoans are similar in that all three have lophophores, the morphology of bryozoans differs from that of phoronids and brachiopods in some ways. The evolution of bryozoans involved the formation of colonies and an extreme reduction in body size. These changes in morphology might associated with genetic changes, which have been detected by molecular methods and which explain why bryozoans lack a strictly established position in the phylogenetic tree of bilaterians. At the same time, bryozoans retained some ancestral morphological features and especially the lophophore. For this reason, our morphological data on the lophophore innervation indicate that the lophophorates are monophyletic. To decline the lophophorates monophyly we should suggest the independent origin of the lophophore - a specific tentacular structure having specific innervation - in both Bryozoa and Brachiozoa.

\section{Acknowledgements}

This work was done with support from the Russian Foundation for Basic Research (comparative analysis, \#17-04-00586) and from the Russian Science Foundation (processing of the paper, \#14-50-00029).

\section{References}

Bemmelen J.Fv., van. 1883. Untersuchungen über den anatomichen und histologichen Bau der Brachiopoda Testicardina // Jena. Z. Naturwiss.(Leipzig). Bd.16. S.88-161.

Blochmann F. 1892. Die Anatomie von Crania anomala (Müller) // F. Blochmann (Hrsg.). Untersuchungen über den Bau der Brachiopoden I. Jena: Gustav Fischer. S.1-65.

Blochmann F. 1900. Die Anatomie von Discinisca lamellosa (Broderip) und Lingula anatina (Bruguiére) // F. Blochmann (Hrsg.). Untersuchungen über den Bau der Brachiopoden II. Jena: Gustav Fischer. S.1-124.

Emig C.C. 1976. Le lophophore-structure significative des Lophophorates (Brachiopodes, Bryozoaires, Phoronidiens) // Zool. Scr. Vol.5. No.1-4. P.133137.

Fernández I., Pardos F., Benito J., Roldan C. 1996. Ultrastructural observation on the phoronid nervous system // J. Morph. Vol.230. P.265-281.

Hausdorf B., Helmkampf M., Nesnidal M.P., Bruchhaus I. 2010. Phylogenetic relationships within the lophophorate lineages (Ectoprocta, Brachiopoda and Phoronida) // Mol. Phylogenet. Evol. Vol.55. No.3. P.11211127.

Hyman L.H. 1959. The lophophorate coelomates - phylum Brachiopoda // L.H. Hyman (ed.). The Invertebrates: Smaller Coelomate Groups: Chaetognatha, Hemichordata, Pognophora, Phoronida, Ectoprocta, Brachipoda, Sipunculida: the Coelomate Bilateria. Vol.5. New York: McGraw-Hill. P.516-609.

James M. 1997. Brachiopoda: Internal anatomy, Embryology, and Development // F.W. Harrison, R.M. Woollacott (eds.). Microscopic Anatomy of Invertebrates. Vol.13. Lophophorates, Entoprocta, and Cycliophora. NY: Willey-Liss. P.297-407.

Jang K., Hwang U. 2009. Complete mitochondrial genome of Bugula neritina (Bryozoa, Gymnolaemata, Cheilostomata): phylogenetic position of Bryozoa and phylogeny of lophophorates within the Lophotrochozoa // BMC Genomics. Vol.10. No.1. P.1-18.

Kocot K.M., Struck T.H., Merkel J., Waits D.S., Todt Ch., Brannock P.M., Weese D.A., Cannon J.T., Moroz L.L., Lieb B., Halanych K.M. 2017. Phylogenomics of Lophotrochozoa with consideration of systematic error // System. Biol. Vol.66. No.2. P.256-282.

Lutaud G. 1973. L'innervation du lophophore chez le Bryozoaire chilostome Electra pilosa (L.) // Z. Zellforsch. Mikrosk. Anat. T.140. No.2. P.217-234.

Mukai H., Terakado K., Reed C.G. 1997. Bryozoa // F.W. Harrison, R.M. Woollacott (eds.). Microscopic Anatomy of Invertebrates. Vol.13. Lophophorates, Entoprocta, and Cycliophora. NY: Willey-Liss. P.45-206.

Nesnidal M.P., Helmkampf M., Meyer A., Witek A., Bruchhaus I., Ebersberger I., Hankeln T., Lieb B., Struck T.H., Hausdorf B. 2013. New phylogenomic data support the monophyly of Lophophorata and an Ectoproct-Phoronid clade and indicate that Polyzoa and Kryptrochozoa are caused by systematic bias // BMC Evol. Biol. Vol.13: 253.

Pardos F., Roldan C., Benito J., Emig. C.C. 1991. Fine structure of the tentacles of Phoronis australis // Acta Zool. Vol.72. No.2. P.81-90.

Reed C.G., Cloney R.A. 1977. Brachiopod tentacles: ultrastructure and functional significance of the connective tissue and myoepithelial cells in Terebratalia // Cell Tiss. Res. Vol.185. P.17-42. 
Schwaha T., Wanninger A. 2012. Myoanatomy and serotonergic nervous system of plumatellid and fredericellid phylactolaemata (Lophotrochozoa, Ectoprocta) // J. Morphol. Vol.273. No.1. P.57-67.

Schwaha T.F., Wanninger A. 2015. The serotonin-lir nervous system of the Bryozoa (Lophotrochozoa): a general pattern in the Gymnolaemata and implications for lophophore evolution of the phylum // BMC Evol. Biol. Vol.15. No.1: 223.

Schwaha T., Wood T.S. 2011. Organogenesis during budding and lophophoral morphology of Hislopia malayensis Annandale, 1916 (Bryozoa, Ctenostomata) // BMC Dev. Biol. Vol.11. No.1: 23.

Schwaha T., Wood T.S., Wanninger A. 2011. Myoanatomy and serotonergic nervous system of the ctenostome Hislopia malayensis: evolutionary trends in bodyplan patterning of ectoprocta// Front. Zool. Vol.8. No.1: 11

Shunkina K.V., Zaytseva O.V., Starunov V.V., Ostrovsky A.N. 2015. Comparative morphology of the nervous system in three phylactolaemate bryozoans // Front. Zool. Vol.12: 28.

Silén L. 1954. On the nervous system of Phoronis // Ark. Zool. Nye Ser. Bd.6. S.1-40.

Storch V., Welsch U. 1976. Elektronenmikroskopische und enzymhistochemische Untersuchungen über Lophophor und Tentakeln von Lingula unguis (L.) (Brachiopoda) // Zool. Jb., Anat. Bd.96. S.225-237.

Temereva E.N. 2015. Organization of the coelomic system in Phoronis australis (Lophotrochozoa: Phoronida) and consideration of the coelom in the lophophorates // J. Zool. Vol.296. No.2. P.79-94.

Temereva E.N., Kosevich I.A. 2016. The nervous system of the lophophore in the ctenostome Amathia gracilis provides insight into the morphology of ancestral ectoprocts and the monophyly of the lophophorates // BMC Evol. Biol. Vol.16. No.181.

Temereva E.N., Malakhov V.V. 2009. Microscopic anatomy and ultrastructure of the nervous system of Phoronopsis harmeri Pixell, 1912 (Lophophorata: Phoronida) // Russ. J. Mar. Biol. Vol.35. No.5. P.388404.

Temereva E.N., Malakhov V.V. 2011. The evidence of metamery in adult brachiopods and phoronids // Invert. Zool. Vol.8. No.2. P.91-112.

Temereva E.N., Tsitrin E.B. 2014. Development and organization of the larval nervous system in Phoronopsis harmeri: new insights into phoronid phylogeny // Front. Zool. Vol.11. No.1: 3.

Temereva E.N., Tsitrin E.B. 2015. Modern data on the innervation of the lophophore in Lingula anatina (Brachiopoda) support the monophyly of the lophophorates // PLoS ONE. Vol.10. No.4:e0123040.

Weber A.V., Wanninger A., Schwaha T.F. 2014. The nervous system of Paludicella articulata - first evidence of a neuroepithelium in a ctenostome ectoproct // Front. Zool. Vol.11. No.1: 89.

Responsible editor K.G. Mikhailov 